\title{
Reefs and bioaccumulations in the Miocene deposits of the North Croatian Basin - Amazing diversity yet to be described
}

Original scientific paper

\author{
Jasenka Sremac'; Marija Bošnjak Makovec²; Davor Vrsaljko²; Bojan Karaica; Kristina Tripalo; \\ Karmen Fio Firi'; Ana Majstorović Bušić5; Tihomir Marjanac ${ }^{1}$
}

${ }^{1}$ University of Zagreb, Faculty of Science, Department of Geology, Horvatovac 102a, HR-10000 Zagreb

${ }^{2}$ Croatian Natural History Museum, Demetrova 1, HR-10000 Zagreb

${ }^{3}$ Hanamanova 1c, HR-10000 Zagreb

${ }^{4}$ Šestinski vrh 43a, HR-10000 Zagreb

${ }^{5}$ INA-Industry of Oil Plc., Šubićeva 29, HR-10000 Zagreb

\begin{abstract}
During the early stages of the Middle Miocene transgression marine biota invaded the newly formed Paratethys Sea. Reefs and reef-like structures particularly flourished with life, supported by the favourable climate conditions. Miocene biogene buildups show a variety of fossil assemblages and lithologic features. The main reef-builders were bryozoans, coralline algae, corals, oysters, vermetids, sponges and serpulids. Water turbidity and depth were major ecological factors controlling the reef biota. Lithofacies types at the studied localities in Northern Croatia show significant similarity with the Upper Langhian (Middle Badenian) of the Leitha Mountains in Austria, but can also be well compared with Miocene to recent reef structures in the Mediterranean. The Miocene reef-like buildups exhibit different porosity rates and other lithological characteristics.
\end{abstract}

\section{Keywords}

Biogene buildups, Badenian, Central Paratethys, Croatia

\section{Introduction}

Transgression of the Paratethys Sea reached its maximum during the Middle Miocene, when sea covered the vast areas of European and west Asian plains, extending from the Alps towards the Aral Sea (Rögl, 1996, 1998, 1999; Steininger and Wessely, 2000; Popov et al., 2004; Kováč et al., 2007; Piller et al., 2007; Ćorić et al., 2009; Malvić, 2012). Tectonic movements, eustatic sea level rise, and palaeorelief forms with different basal rocks, affected the timing of the initial flooding and development of the diverse palaeocommunities. Initial marine flooding in the North Croatian Basin (NCB) was long presumed to be of Carpathian age (Šikić, 1968; Šikić et al., 1977, 1979; Basch, 1983; Pavelić, 2001; Pavelić et al., 2003). Ćorić et al. (2009) integrated the data from calcareous nannoplankton, planktic and benthic foraminifera, and proposed the Early Badenian (Middle Langhian, according to the International Chronostratigraphic Chart, http://www.stratigraphy.org/ICSchart/ChronostratChart2015-01.pdf, September 2015) age of the initial Middle Miocene transgression in the North Croatian Basin, a part of the Pannonian Basin System (PBS; Figure 1).

Palaeozoic, Mesozoic, and, sometimes Early Miocene rocks represent the bedrock of the transgressive Middle Miocene sequences. Transgressive breccias and conglomerates are common, but in some areas coralgal buildups directly overlay the basal rocks. Badenian-Pliocene interval is the period of the maximum sediment deposition 
(Malvić and Velić, 2010, 2011) and Badenian reefs and reef-like structures are the major source of carbonate components within the Badenian and Sarmatian clastic sedimentary rocks (Malvić, 2012).

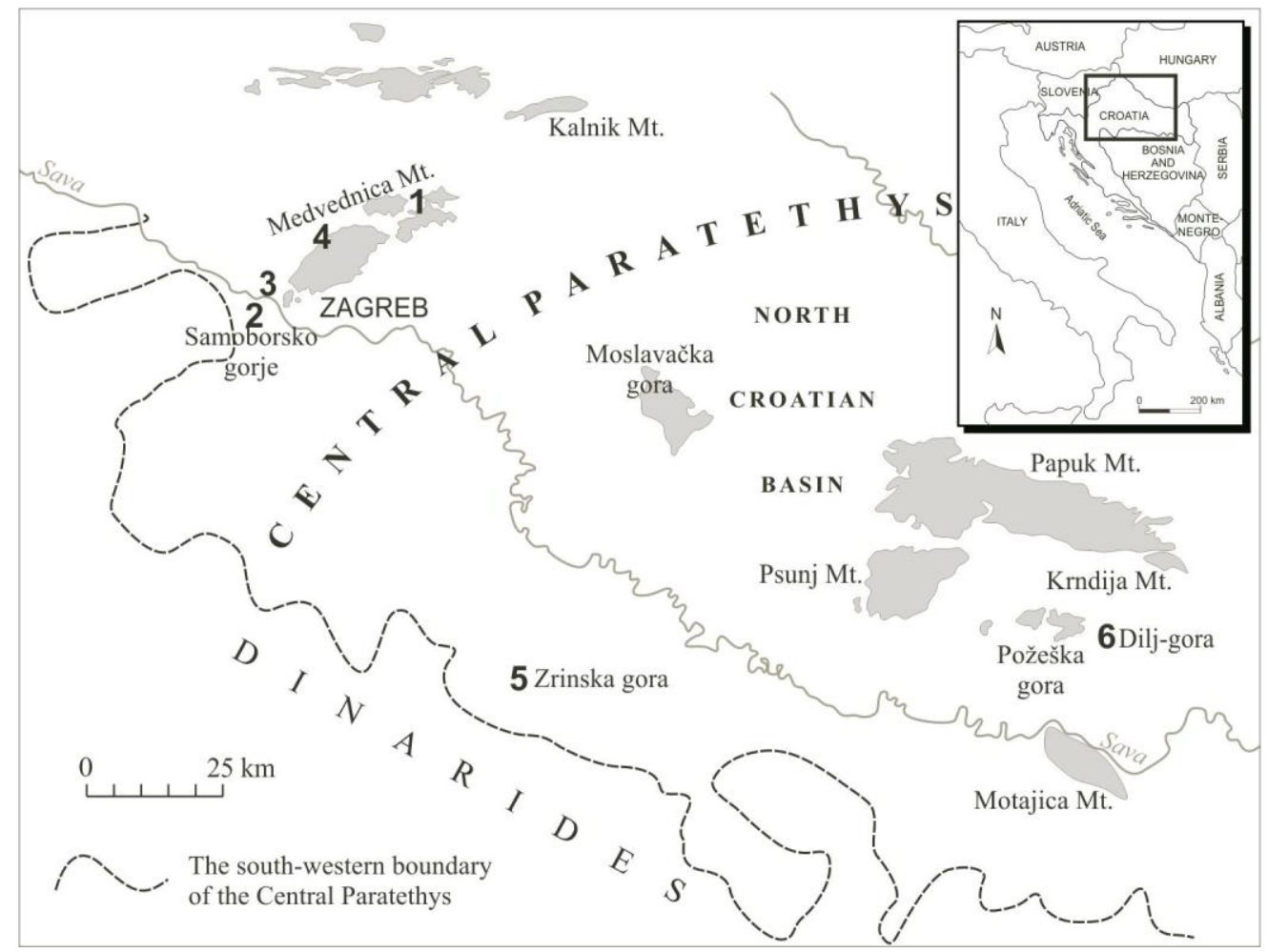

Figure 1: Palaeogeographic map of the North Croatian Basin (modified after Rögl, 1998; Pavelić, 2oo1; Corić et al., 2009; Martinuš et al., 2013). Grey color is marking isolated mountains. Numbers are marking studied areas: 1. eastern part of the Medvednica Mt.; 2. Samoborsko gorje; 3. Marijagorička brda; 4. northern part of the Medvednica Mt., Stubičke Toplice; and areas used for correlation: 5. Zrinska gora, 6. Dilj-gora

\section{Materials and Methods}

Miocene reefs and reef-like structures were studied in the field during 2014 and 2015 in Northern Croatia (Medvednica Mt., Samoborsko gorje, Marijagorička brda and the vicinity of Stubičke Toplice Spa; Figure 1). Study areas were chosen according to the previously published data (e.g. Kochansky, 1944; Kranjec et al., 1973; Šikić et al., 1977; Šikić et al., 1979; Basch et al., 1981; Basch, 1983). The investigation also includes samples from bore-holes, which contain Badenian reef and reef-like structures.

Twenty samples were chosen for laboratory preparations. Polished tiles were prepared in the Wet Laboratory of the Department of Geology, Faculty of Science in Zagreb. Eight samples from different lithologies were then chosen for further preparation, and twenty-two thin sections were prepared for palaeontological and sedimentological analyses.

Thin sections were studied by using stereo-microscope Olympus-SZX10 and polarizing microscope Leica Laborlux 11, photographed by a Canon EOS 1100 - camera and saved through the Quick PHOTO CAMERA 3.0 programme.

\section{Miocene reef-builders}

Corals, coralline algae and bryozoa were the major reef-builders at the Miocene carbonate platforms in Europe (e.g. Wiedl et al., 2013), and represent the most common fossil groups in the studied samples. Coralline algae 
are very abundant in the Middle Miocene of the NCB, but are commonly associated with other reef-building biota.

\section{I. Bryozoans}

Fossil bryozoans (Figure 2a) are generally common in shallow-marine deposits. They flourished in the Paratethys Sea during the Early Badenian "bryozoan event" (Zágoršek et al., 2008a; Key et al., 2013). Bryozoans often build reef structures in association with other biota: most usually corals and calcareous algae. Bryozoan colonies are very useful in palaeoenvironmental reconstructions (e.g. Hageman et al. 1997, 1998; Moissette et al. 2006, 2007; Holcová and Zágoršek, 2008; Zágoršek et al. 2008a, b, 2010). Using stable isotopes from bryozoan skeletons, Key et al. (2013) calculated the Middle Miocene temperatures to range from 12 to $21^{\circ} \mathrm{C}$.
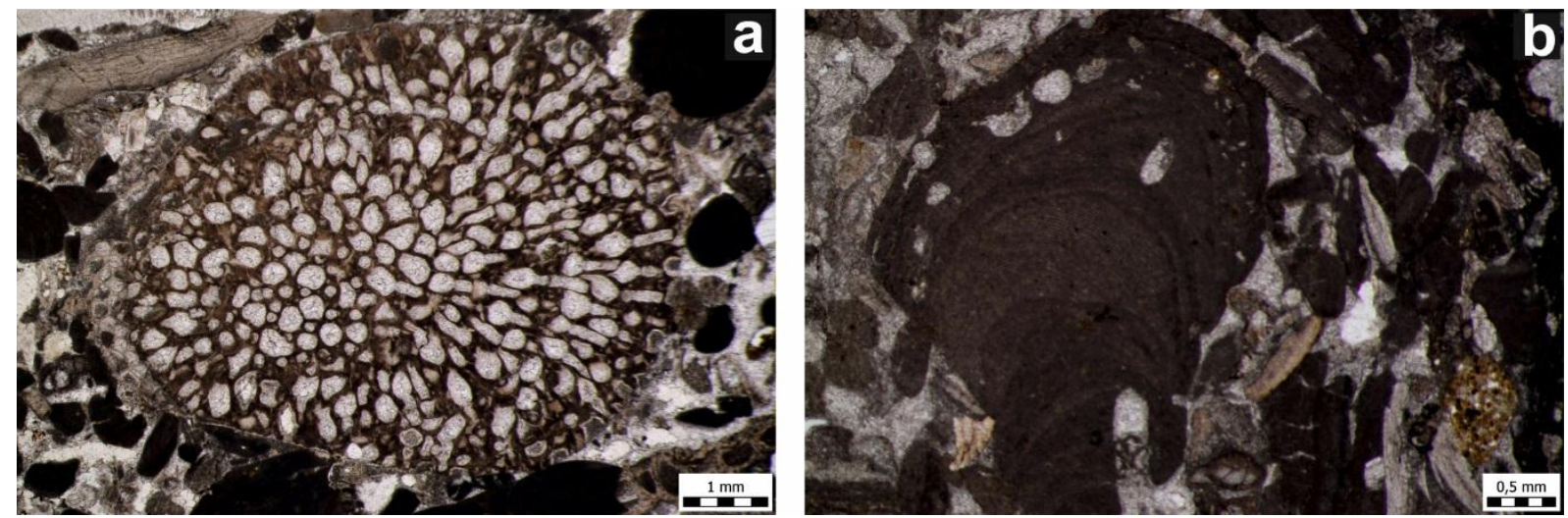

Figure 2: Thin sections showing typical Middle Miocene reef-builders in the NCB (Medvednica Mt.); a) bryozoan colony; b) coralline alga

In the NCB bryozoans are in most cases associated with coralline algae and were found at almost all of the studied localities. Corallinales add to the stability of the bryozoan biolithites and help in their preservation, although bryozoan fragments can be commonly found in bioclastic deposits around the reef buildups, and even redeposited in deeper marine environments (Martinuš et al., 2013; Posedi et al., 2014).

\subsection{Coralline algae}

Red algae from the order Corallinales (Figure 2b) are characterized with thick magnesium-carbonate deposits within the cell walls. They are common in ancient and modern reefs, in most cases appearing as branches or rhodoliths (Basso et al., 2008; Hrabovsky, 2013), and sometimes acting as laminar encrusters.

In the Middle Miocene of the NCB they are the most common reef builders, producing biolithites known as "Lithothamnium limestone", "Lithothamnium sandstone" and "Litavac" deposits of the Upper Badenian (Lower Serravalian) age (Kochansky, 1944; Šikić, 1968; Vrsaljko et al., 2005, 2006; Basso et al., 2008). All of these types can be found at the studied localities, or sometimes even at one locality, showing visible palaeoenvironmental varieties even within small study areas.

Coralgal biolithites are among the first biogene reef-like structures after the marine transgression of the Paratethys Sea. They are associated with tolerant and wide-spread bivalves (e.g. oysters, pectinids, cardiids, Lucinoma, Corbula, Tellina), gastropods (Conus, Ficus), echinoids (Clypeaster) and benthic foraminifera, ostracods, bryozoans, sponges and corals. Typical palaeoenvironment of coralgal buildups is situated within the infralittoral to shallow circalittoral zones (Vrsaljko et al., 2007; Basso et al., 2008). The most common species is Lithothamnion valens, with unattached, branched forms, still living today in the Mediterranean and the Adriatic Sea (Basso et al., 2008). Small rhodoliths are usually composed of Phymatolithon calcareum and 
Mesophyllum roveretoi. Fragments of coralgal buildups are common in the surrounding bioclastic (wackestonepackstone-floatstone-rudstone) deposits.
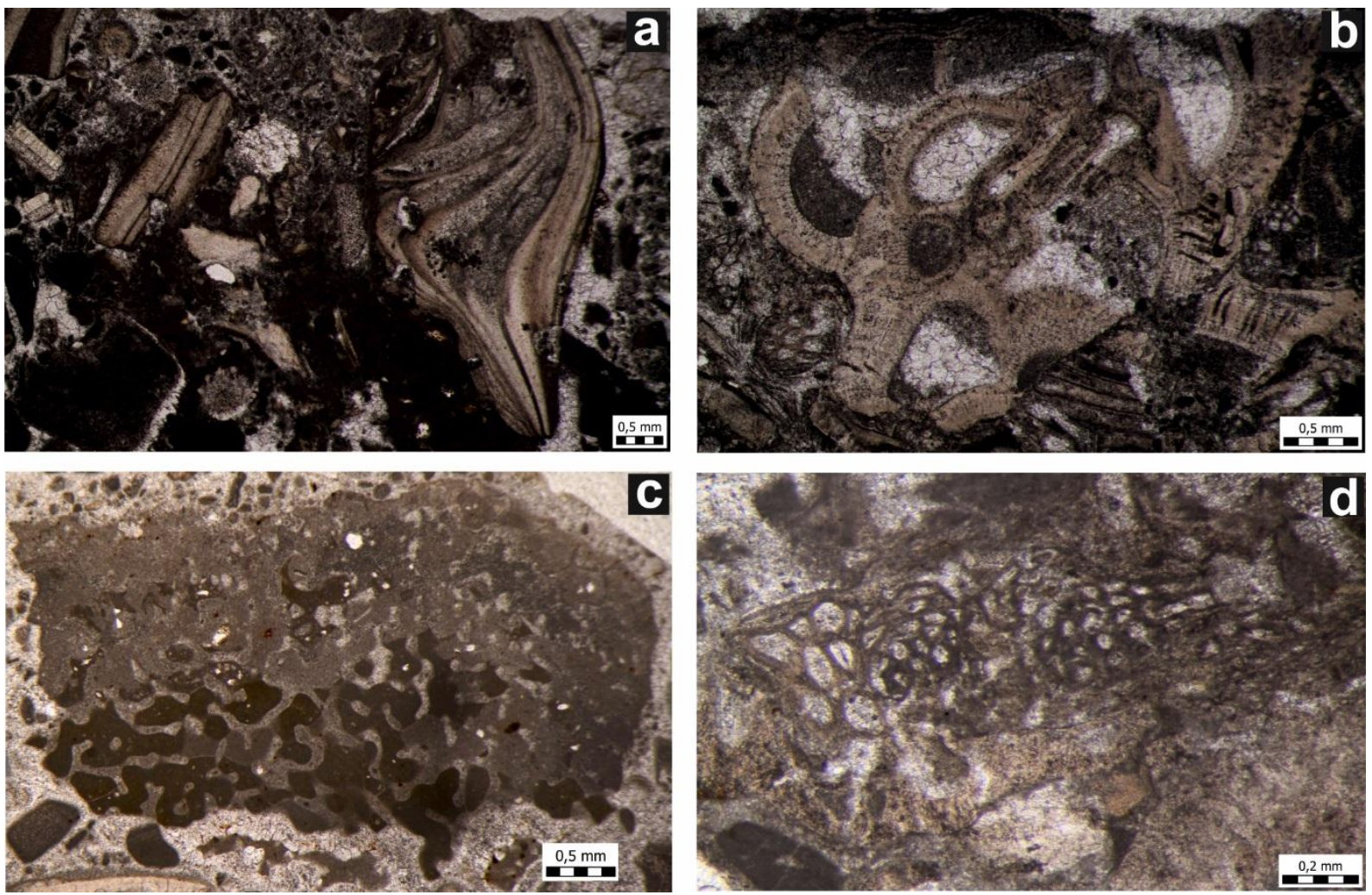

Figure 3: Diverse secondary reef builders in thin sections from the Miocene coralgal-bryozoan facies: a) oysters; b) vermetids; c) Porites sp.; d) nubeculariid foraminifera

\subsection{Corals}

Corals in the Middle Miocene reef facies of the NCB are outnumbered by bryozoans and coralline algae (Kochansky, 1944). They are often associated with Corallinales and found as casts and moulds, as their aragonite skeletons are dissolved in porous sediments. Corals are found at several studied localities in the Medvednica Mt. The intriguing genus Porites, similar to calcareous sponges, is commonly associated with corals (e.g. Piller et al., 2007). It occurs within the coralgal-bryozoan facies (Figure 3c). Badenian corals are also known from the Zrinska gora (Martinuš et al., 2013) and Dilj-gora (Šparica et al., 1988).

Colonies of Tarbellastrea reussiana are rather common in the wider area (Riegl and Piller, 2000; Wiedl et al., 2013) and branching finger-like Porites was producing biostromes (Riegl and Piller, 2000). Kochansky (1944) reported a few coral taxa from the Badenian coralgal deposits in the NCB: colonial Prionastraea neugeboreni and solitary Flabellum sp.

\subsection{Oysters}

Miocene oysters were widely spread and often very large. They are generally well preserved, due to their massive calcite shells (Figures 3a, 4). The most common genera in reef environments are Ostrea, Cubitostrea, Hyotissa and Crassostrea (Kochansky, 1944; El-Hedeny, 2005; Vrsaljko et al., 2007; Riegl and Piller; 2000; Wiedl et al., 2013). Oysters are almost always associated with coralgal facies, but sometimes they produce coquinas, growing one upon another (e.g. Hyotissa; Wiedl et al., 2013). They are among the first to enter the new Paratethys Sea and their shells are commonly found in the base of the transgression. They are also often subject to bioerosion by clionid sponges and/or date mussels (Lithophaga) (El-Hedeny, 2005; Figure 4b).

The Mining-Geology-Petroleum Engineering Bulletin, 2015, pp. 19-29 @ The Author(s), DOI: 10.17794/rgn.2016.1.2 

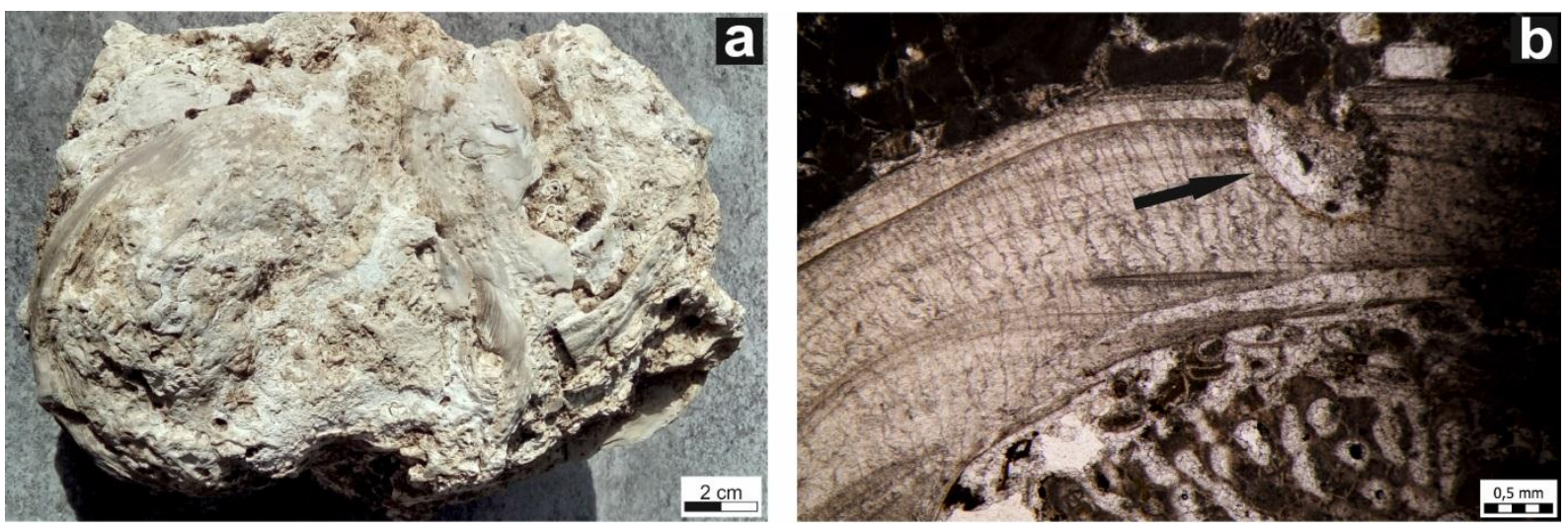

Figure 4: a) cluster of Miocene oysters, Marijagorička brda; b) mussel or sponge bioerosion on oyster shell, marked with arrow; thin section, Medvednica Mt.

\subsection{Vermetids}

Vermetids are obscure reef-building gastropods characterized by irregular shell growth. Their reefs are usually associated with serpulids, bryozoans and coralline algae, and occur from the upper subtidal zones down to a depth of $50 \mathrm{~m}$. The oldest occurences are reported from the Badenian, and are well known from the Mediterranean (Vescogni et al., 2008). Vermetids of the genus Petaloconchus produced elongated structures along the coastal ramps and isolated carbonate platforms of the Paratethys Sea, in association with coralline algae and other encrusters (Pisera, 1985; Vescogni et al., 2008). Vermetids occur sporadically within the Badenian coralgal-bryozoan facies in the Medvednica Mt. region (Figure 3b).

\subsection{Serpulids}

Serpulids are polychaetes (segmented worms) with carbonate tubes, common in modern coralligenous assemblages. In reef environments, they usually live in microcavities as endobionts (Pansini et al., 2009). Some gregarious polychaetes produce concretions in modern coastal environments at a depth of up to 2 meters (Bressan et al., 2009). They can attach themselves to all kinds of hard surfaces and can tolerate salinity variations and high rates of eutrofication. Modern serpulids produce reefs quickly, at speeds of up to $30 \mathrm{~mm}$ per month, often in combination with secondary reef builders, such as bryozoans, barnacles and mussels. Fossil serpulids were first described more than 300 years ago, but palaeontologists generally pay little attention to the group (Ippolitov et al., 2014). A Miocene occurrence of tube worms was recorded by Radwańska (1994), Taylor et al. (2006) and Jäger and Schneider (2009). Such reef-like constructions are more common during the Sarmatian than during the Badenian, but they were recently found in the Marijagorička brda near Zagreb (Figure 1).

\subsection{Sponges}

Sponge fossil records from the Miocene reef buildups are scarce. Sometimes siliceous spicules appear sporadically among the reef biota. Clionid sponges leave their boring traces on large mollusk shells (e.g. oysters) and rhodoliths (Figure 4b) (Checconi and Monaco, 2008). Psammobiontic sponge genus Aplysina is known from the Miocene of Belgium (Herman and Marquet, 2007) and Italy (Reuter et al., 2013). Some Badenian buildups from Medvednica Mt. might comprise Aplysina-like sponges, but they require further study.

\subsection{Sessile foraminifera}

The Mining-Geology-Petroleum Engineering Bulletin, 2015, pp. 19-29 @ The Author(s), DOI: 10.17794/rgn.2016.1.2 
Some miliolid foraminifera live as stationary epifaunal suspension feeders and contribute to the formation of reefs and reef-like structures since the Palaeozoic era. Nubeculariid reefs were reported from the Miocene of the Paratethys by several authors (e.g. Pisera, 1996; Hyžný et al., 2012), but they are more common during the Sarmatian (Kochansky, 1944; Kochansky-Devidé and Bajraktarević, 1981; Vrsaljko et al., 2006; Cornée et al., 2009). Miliolid encrusters sporadically occur within the Badenian coralgal-bryozoan facies in Medvednica Mt. (Figure 3d).

\subsection{Bryopsidalean algae}

The genus Halimeda is well known from the modern Mediterranean seaweed flora. It is also one of the important carbonate producers in Cenozoic and tropical reefs. These tropical algae invaded the higher latitudes, including the Mediterranean and the Central Paratethys during the Middle Miocene Climate Optimum (Bucur et al., 2011; Reuter et al., 2012). Fragments of Halimeda sp. and Neomeris sp. in the rhodolitic facies were recognized in the Middle Miocene deposits of Romania (Bucur et al., 2011). They also occur in some coralgal-bryozoan boundstones in Medvednica Mt.

\section{Discussion and conclusion}

Reefs and reef-like structures depend on two life strategies: gregariousness (e.g. serpulids and vermetids) and colonialism (corals, bryozoans). Among the modern bioconstructions, coralligenous frameworks are extremely important and very complex, with various secondary reef-builders (Cosentino et al., 2009).

Today, coralligenous bioconstructions are produced as concretions in dimly lit conditions, sufficient for shadeloving (sciaphilic) algae, in constant temperatures, uniform salinity and low water energy. They develop on both - rocky and mobile substrates in lower littoral zones and sometimes on coastal debris. Their growth starts with the formation of rhodoliths within the sands and gravels (platform coralligenous assemblages) (Cosentino et al., 2009). This observation helps us understand the early appearance of coralgal buildups, near the base of the Middle Miocene transgression. Initial rhodolith phase results in loosely bound bioclastic deposits.

The coralgal skeletal associations are often connected with the coralgal-bryozoan associations, and commonly develop in warm-temperate to subtropical areas, or transitional zone between cold temperate and tropical areas (cf. Martinuš et al., 2013, and references within). Due to the consideration that the investigated areas of the NCB in Miocene were situated $2-5^{\circ}$ further south than today (Randazzo et al., 1999), deposition in the subtropical zone can be proposed.

The formation of reefs and bioaccumulations (coralgal crusts around the bioeroded pebbles) is influenced by different factors [sea-level oscillations, wind and storm main direction (ripple marks, dunes), progradation of the alluvial fan, etc.] which can be seen in the Badenian sequence from the southwestern slopes of Medvednica Mt. Detailed study in the wider area would give insight into the general sea-level, sea and wind-current patterns, as well as the palaeogeographic reconstruction of the wider area.

Diagenetic processes, depending on environmental conditions, additionally increase the porosity of the studied deposits, due to the dissolution of aragonitic bioclasts (Figures 4, $\mathbf{5}$ and 6). This dissolution is aggressive in very shallow habitats and decreases with depth. These processes enabled some important accumulations of hydrocarbons in Croatia, such as the oil-producing area Beničanci in Slavonia (Tišljar, 1993; Malvić and Đureković, 2003). Variable porosity of coralgal buildups was observed during the field work in Medvednica Mt. Rock samples with large rhodoliths exhibited the highest porosity (Figure 5a-c). Rhodolith facies showed a combination of primary and secondary porosity (Figure 5d), while framestones with bryozoan domination are the most compact.

High diversity of biota in the Middle Miocene (Badenian, Langhian) reefs and reef-like structures in Northern Croatia was recognized early by Kochansky (1944). A recent study of similar bioconstructions from the Vienna Basin (Wiedl et al., 2013) can be an excellent base for further lithological and palaeontological research of these interesting deposits in Croatia.

The Mining-Geology-Petroleum Engineering Bulletin, 2015, pp. 19-29 @ The Author(s), DOI: 10.17794/rgn.2016.1.2 

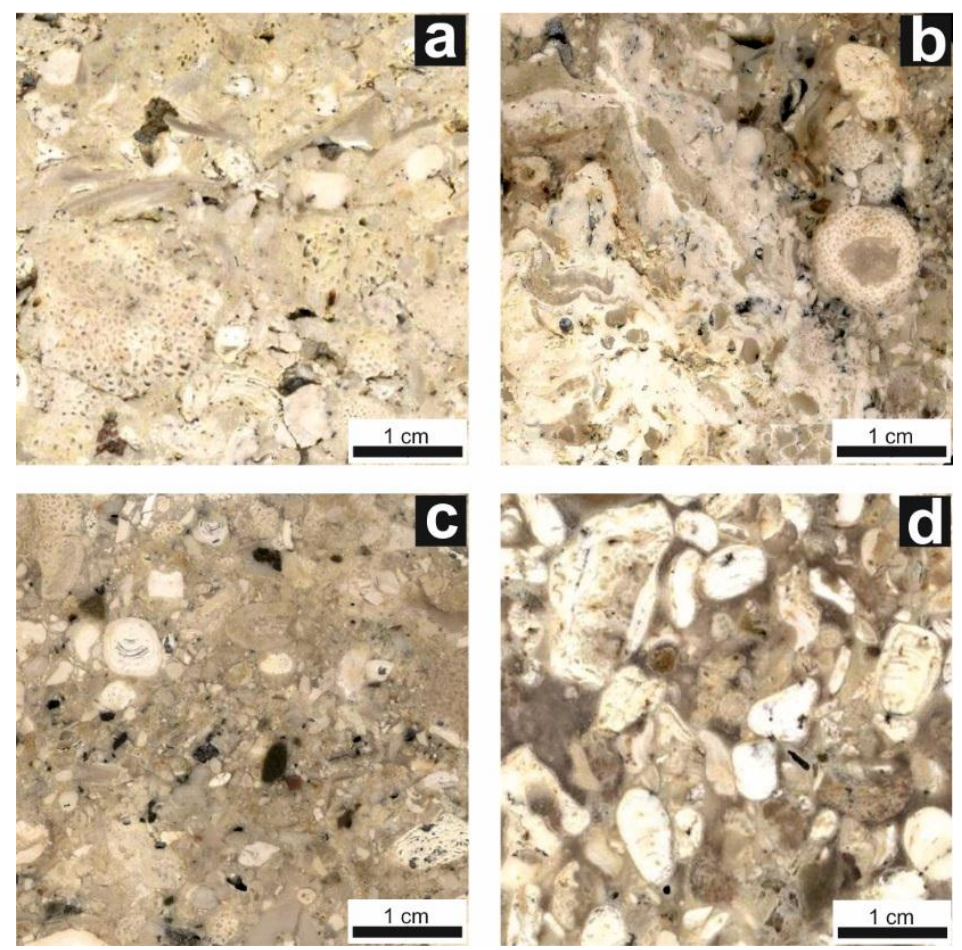

Figure 5: Polished surfaces of different samples of the Miocene coralgal-bryozoan buildups from Medvednica Mt. Higher secondary porosity is visible in samples a, b and c. Sample d represents the rhodolith facies, with a combination of primary and secondary porosity.

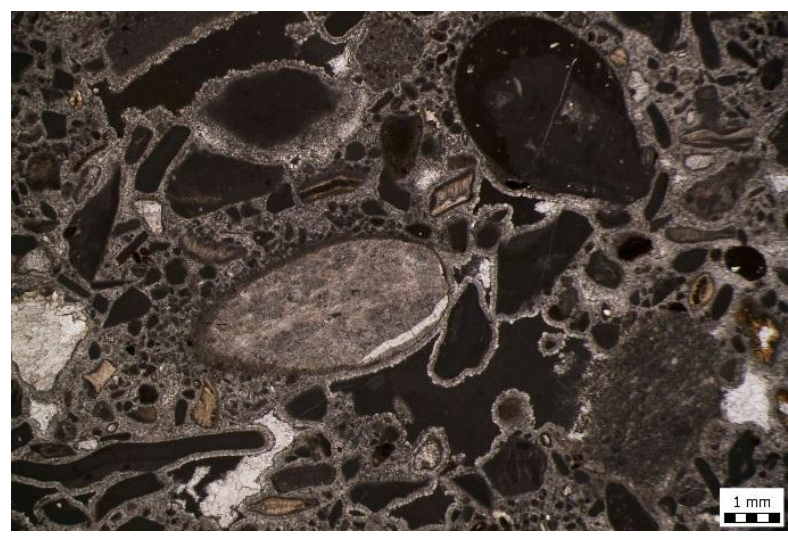

Figure 6: Secondary porosity after the dissolution of aragonite clast. A thin section from the Middle Miocene wackestone (Medvednica Mt.), surrounding the coralgal-bryozoan bioconstructions.

\section{Acknowledgement}

This research was a part of the University of Zagreb financial project support in 2013 and 2014 for the "Development of geomathematical methods for the analysis of Neogene depositional environments in the Croatian part of the Pannonian Basin System" (head T. Malvić). The authors wish to thank Robert Koščal and Željko Ištuk from the Faculty of Science, University of Zagreb, as well as Renato Drempetić, for tehnical support.

The authors are grateful to both reviewers whose suggestions helped us to improve our manuscript. 


\section{References}

Avanić, R., Kovačić, M., Pavelić, D., Miknić, M., Vrsaljko, D., Bakrač, K. and Galović, I. (2003): The Middle and Upper Miocene Facies of Mt. Medvednica (Northern Croatia). In: Vlahović, I. and Tišljar, J. (eds.): Evolution of Depositional Environments from the Palaeozoic to the Quaternary in the Karst Dinarides and the Pannonian Basin. 22nd IAS Meeting of Sedimentology, Opatija, Field Trip Guidebook, 167-172, Zagreb.

Basch, O., Šikić, K., Šimunić, A., Brkić, M., Pikija, M., Jamičić, D., Galović, I., Korolija, B., Pavičić, A., Šparica, M. and Hećimović, I. (1981): Osnovna geološka karta SFRJ 1:100000, list Ivanić-Grad (Basic Geological Map of SFRY 1:100000, Ivanić-Grad sheet). Geol. zavod, Zagreb, Sav. Geol. zavod, Beograd. (in Croatian)

Basch, O. (1983): Osnovna geološka karta SFRJ 1:100000. Tumač za list Ivanić-Grad. (Basic Geological Map of SFRY 1:100000. Geology of the Ivanić-Grad sheet). Geol. zavod, Zagreb, Sav. geol. zavod, Beograd, 66 p. (in Croatian)

Basso, D., Vrsaljko, D. and Grgasović, T. (2008): The coralline flora of a Miocene maërl: the Croatian "Litavac". Geologia Croatica, 61/2-3, 333-340.

Bressan, G., Chemello, R., Flavia Gravina, M., Gambi, M.C., Peirano, A., Cocito, S., Rosso, A. and Turisi, A. (2009): Other types of bioconcretions. In: Cosentino, A., La Posta, A., Morandini, C. and Muscio, G. (eds.): Marine bioconstructions - Nature's architectural seascapes. Italian habitats. - Museo Friulano di Storia Naturale, Udine, Italy, 89-113, 159 p.

Bucur, I.I., Saint Martin, J.-P., Filipescu, S., Săsăran, E. and Pleş, G. (2011): On the presence of green algae (Dasycladales, Bryopsidales) in the Middle Miocene deposits from Podeni (western border of the Transylvanian basin, Romania). Acta Palaeontologica Romaniae, 7, 69-75.

Checconi, A. and Monaco, P. (2008): Trace fossil assemblages in rhodoliths from the Middle Miocene of Mt. Camposauro (Longano Formation, Southern Apennines, Italy). Studi Trent. Sci. Nat., Acta Geol., 83, 165-176.

Cosentino, A., La Posta, A., Morandini, C. and Muscio, G. (eds.) (2009): Marine bioconstructions - Nature's architectural seascapes. Italian habitats. - Museo Friulano di Storia Naturale, Udine, Italy, 159 p.

Cornée, J.-J., Moissette, P., Saint Martin, J.-P., Kázmér, M., Tóth, E., Görög, A., Dulai, A. and Müller, P. (2009): Marine carbonate systems in the Sarmatian (Middle Miocene) of the Central Paratethys: the Zsámbék Basin of Hungary. Sedimentology, 56/6, 1728-1750. DOI 10.1111/j.1365-3091.2009.01055.x

Ćorić, S., Pavelić, D., Rögl, F., Mandic, O., Vrabac, S., Avanić, R., Jerković, L. and Vranjković, A. (2009): Revised Middle Miocene datum for initial marine flooding of North Croatian Basins (Pannonian Basin System, Central Paratethys). Geologia Croatica, 62/1, 31-43.

El-Hedeny, M.M. (2005): Taphonomy and Paleoecology of the Middle Miocene oysters from Wadi Sudr, Gulf of Suez, Egypt. Revue de Paléobiologie, Genève, 24 (2), 719-733.

Hageman, S.J., Bone, Y., McGowran, B. and James, N. P. (1997): Bryozoan colonial growth-forms as paleoenvironemental indicators: evaluation of methodology. Palaios, 12, 405-419.

Hageman, S.J., Bock, P.E., Bone, Y. and McGowran, B. (1998): Bryozoan growth habits: classification and analysis. Journal of Paleontology, 72, 418-436.

Herman, J. and Maquet, R. (2007): Le Miocène du Deurgancdock à Doel. Memoirs of the Geological Survey of Belgium, 54, 149 p., Royal Belgian Institute of Natural Sciences.

Holcová, K. and Zágoršek, K. (2008): Bryozoa, foraminifera and calcareous nannoplankton as environmental proxies of the "bryozoan event" in the Middle Miocene of the Central Paratethys (Czech Republic). Palaeogeography, Palaeoclimatology, Palaeoecology, 267, 216-234. doi:10.1016/j.palaeo.2008.06.019

Hrabovský, J. (2013): Negenikulátne koralinné riasy (Corallinales, Sporolithales, Rhodophyta) z litotamniových vápencov lokality Vrchná hora pri Stupave (Viedenská panva, Slovensko). Mineralia Slovaca, 45, 23-34.

Hyžný, M., Hudáčková, N., Biskupič, R., Rybár, S., Fuksi, T., Halásová, E., Zágoršek, K., Jamrich, M. and Ledvák, P. (2012): Devínska Kobyla - a window into the Middle Miocene shallow-water marine environments of the Central Paratethys (Vienna Basin, Slovakia). Acta Geologica Slovaca, 4(2), 95-111. (in Slovakian)

Ippolitov, A.P., Vinn, O., Kupriyanova, E.K. and Jäger, M. (2014): Written in stone: history of serpulid polychaetes through time. Memoirs of Museum Victoria, 71, 123-159.

Jäger, M., and Schneider, S. (2009): Serpulidae (Annelida, Polychaeta) from the lower Ottnangian (Late Burdigalian) Upper Marine Molasse of Dommelstadl and Gurlarn (Passau area, Lower Bavaria, SE Germany). Neues Jahrbuch für Geologie und Paläontologie, Abhandlungen, 254, 105-115.

Key, M.M., Zágoršek, K. and Patterson, W.P. (2013): Paleoenvironmental reconstruction of the Early to Middle Miocene Central Paratethys using stable isotopes from bryozoan skeletons. International Journal of Earth Sciences (Geologische Rundschau), 102, 305-318. DOI 10.1007/s00531-012-0786-z

Kochansky, V. (1944): Fauna marinskog miocena južnog pobočja Medvednice (Zagrebačke gore). (Miozäne marine Fauna des südlichen Abhanges der Medvednica (Zagreber Gebirge)). Geol. Vjesnik, Hrv. drž. geol. zav., Hrv. drž. geol. muz., Vol. 2/3, 171-280. (in Croatian)

The Mining-Geology-Petroleum Engineering Bulletin, 2015, pp. 19-29 C The Author(s), DOI: 10.17794/rgn.2016.1.2 
Kováč, M., Andreyeva-Grigorovich, A., Bajraktarević, Z., Brzobohatý, R., Filipescu, S., Fodor, L., Harzhauser, M., Nagymarosy, A., Oszczypko, N., Pavelić, D., Rögl, F., Saftić, B., Sliva, L. and Studencka, B. (2007): Badenian evolution of the Central Paratethys Sea: paleogeography, climate and eustatic sea-level changes. Geologica Carpathica, $58,6,579-606$.

Kranjec, V., Hernitz, Z. and Prelogović, E. (1973): Prilog poznavanju mlađih tercijarnih naslaga Medvednice, sjeverozapadna Hrvatska. (Ein Beitrag zur Kenntnis jüngerer Tertiärschichten des Medvednica-Gebirges, Nordwest Kroatien). Geol. vjesnik, 25, 65-100. (in Croatian)

Malvić, T. (2012): Review of Miocene shallow marine and lacustrine depositional environments in Northern Croatia. Geological Quarterly, 56 (3), 493-504. DOI 10.7306/gq.1035

Malvić, T. and Đureković, M. (2003): Application of methods: Inverse distance weighting, ordinary kriging and collocated cokriging in porosity evaluation, and comparison of results on the Beničanci and Stari Gradac fields in Croatia. Nafta, 54 (9), 331-340.

Malvić, T. and Velić, J. (2010): Relation between effective thickness, gas production and porosity in heterogeneous reservoirs, an example from the Molve Field, Croatian Pannonian Basin. Petrol. Geosc., 16(1), 41-51.

Malvić, T. and Velić, J. (2011): Neogene tectonics in Croatian part of the Pannonian Basin and reflectance in hydrocarbon accumulations. In: Schattner, U. (ed.): New Frontiers in Tectonic Research: at the Midst of Plate Convergence, 215238. InTech.

Martinuš, M., Fio, K., Pikelj, K. and Aščić, Š. (2013): Middle Miocene warm-temperate carbonates of Central Paratethys (Mt. Zrinska Gora, Croatia): paleoenvironmental reconstruction based on bryozoans, coralline red algae, foraminifera, and calcareous nannoplankton. Facies, 59, 3, 481-504. DOI 10.1007/s10347-012-0327-z

Moissette, P., Dulai, A. and Müller, P. (2006): Bryozoan faunas in the Middle Miocene of Hungary: biodiversity and biogeography. Palaeogeography, Palaeoclimatology, Palaeoecology, 233, 300-314. doi:10.1016/j.palaeo.2008.06.019

Moissette, P., Dulai, A., Escarguel, G., Kázmér, M., Müller, P. and Saint Martin, J.-P. (2007): Mosaic of environments by bryozoan faunas from the Middle Miocene of Hungary. Palaeogeography, Palaeoclimatology, Palaeoecology, 252, 530-556. doi:10.1016/j.palaeo.2007.05.010

Pansini, M., Cerrano, C., Cocito, S., Gambi, M.C. and Rosso, A. (2009): Fauna: invertebrates. In: Cosentino, A., La Posta, A., Morandini, C. and Muscio, G. (eds.): Marine bioconstructions - Nature's architectural seascapes. Italian habitats. Museo Friulano di Storia Naturale, Udine, Italy, 49-77, 159 p.

Pavelić, D. (2001): Tectonostratigraphic model for the North Croatian and North Bosnian sector of the Miocene Pannonian Basin System. Basin Research, 12, 359-376.

Pavelić, D., Avanić, R., Kovačić, M., Vrsaljko, D. and Miknić, M. (2003): An outline of the evolution of the Croatian part of the Pannonian Basin System. In: Vlahović, I. and Tišljar, J. (eds.): Field trip guidebook: evolution of depositional environments from the Palaeozoic to the quaternary in the Karst Dinarides and the Pannonian Basin. 22nd IAS meeting of sedimentology. Institute of Geology, Zagreb, 155-161.

Piller, W.E., Harzhauser, M. and Mandic, O. (2007): Miocene Central Paratethys stratigraphy-current status and future directions. Stratigraphy, 4, 2/3, 151-168.

Pisera, A. (1985): Paleoecology and lithogenesis of the Middle Miocene (Badenian) algal vermetid reefs from the Roztocze Hills, southeastern Poland. Acta Geol. Pol., 35, 89-155.

Pisera, A. (1996): Miocene reefs of the Paratethys: a review. In: Franseen, E.K., Esteban, M., Ward,W.C. and Rouchy, J. (eds.), Models for Carbonate Stratigraphy From Miocene Reef Complexes of Mediterranean Region. Concepts in Sedimentology and Paleontology, vol. 5. SEPM, Tulsa, 97-104.

Popov, S.V., Rögl, F., Rozanov, A.Y., Steininger, F.F., Shcherba, I.G. and Kovac, M. (eds.) (2004): LithologicalPaleogeographic maps of Paratethys; 10 maps Late Eocene to Pliocene. Courier Forschungsinstitut Senckenberg, 250, $46 \mathrm{p}$.

Posedi, N., Bošnjak, M., Sremac, J. and Vrsaljko, D. (2014): Srednjomiocenski bryozoa s lokaliteta Pivnice (Dilj gora, Hrvatska) (Middle Miocene Bryozoa from the locality Pivnice (Dilj gora, Croatia)). In: Abolmasov, B., Bogićević, K., Ganić, M., Jelenković, R., Maran Stevanović, A., Matović, V., Ristić Vakanjac, V., Ristović, A. and Rundić, Lj. (eds.): Proceedings of the XVI Serbian Geological Congress - Serbian Geological Society, 197-205. (in Croatian)

Radwańska, U. (1994): Tube-dwelling polychaetes from the Korytnica Basin (Middle Miocene; Holy Cross Mountains, Central Poland). Acta Geologica Polonica, 44, 35-83.

Randazzo, A.F., Müller, P., Lelkes, G., Juhász, E. and Hámor, T. (1999): Coolwater limestones of the Pannonian basinal system, Middle Miocene, Hungary. Journal of Sedimentary Research, 69(1), 283-293.

Reuter, M., Piller, W.E. and Richoz, S. (2012): The dispersal of Halimeda in northern hemisphere mid-latitudes: Palaeobiogeographical insights. Perspectives in Plant Ecology, Evolution and Systematics, 14, 303-309.

Reuter, M., Piller, W.E. and Brandano, M. (2013): Fossil psammobiontic sponges and their foraminiferal residents, Central Apennines, Italy. Palaios, 28, 614-622. DOI 10.2110/palo.2013.p13-004r

The Mining-Geology-Petroleum Engineering Bulletin, 2015, pp. 19-29 @ The Author(s), DOI: 10.17794/rgn.2016.1.2 
Riegl, B. and Piller, W.E. (2000): Biostromal Coral Facies - A Miocene Example from the Leitha Limestone (Austria) and its Actualistic Interpretation. Palaios, 15, 399-413.

Rögl, F. (1996): Stratigraphic correlation of the Paratethys Oligocene and Miocene. Mitt. Ges. Geol. Bergbaust. Wien, 41, 65-73.

Rögl, F. (1998): Palaeogeographic considerations for Mediterranean and Paratethys Seaways (Oligocene to Miocene). Ann. Naturhist. Mus. Wien, 99A, 279-310.

Rögl, F. (1999): Mediterranean and Paratethys. Facts and Hypotheses of an Oligocene to Miocene Paleogeography (Short overview). Geologica Carpathica, 50, 339-349.

Steininger, F.F. and Wessely, G. (2000): From the Tethyan Ocean to the Paratethys Sea: Oligocene to Neogene Stratigraphy, Paleogeography and Paleobiogeohraphy of the circum-Mediterranean region and the Oligocene to Neogene Basin evolution in Austria. Mitt. Österr. Geol. Ges., 92 (1999), 95-116.

Šikić, L. (1968): Stratigrafija miocena sjeveroistočnog dijela Medvednice na osnovu faune foraminifera (Stratigraphy of the Miocene based on foraminifera fauna). Geol. vjesnik, 21, 213-227. (in Croatian)

Šikić, K., Basch, O. and Šimunić, A. (1977): Osnovna geološka karta SFRJ 1:100.000, list Zagreb (Basic Geological Map of SFRY 1:100000, Zagreb sheet). Institut za geološka istraživanja, Zagreb, Savezni geološki zavod, Beograd. (in Croatian)

Šikić, K., Basch, O. and Šimunić, A. (1979): Osnovna geološka karta SFRJ 1:100.000. Tumač za list Zagreb. (Basic Geological Map of SFRY 1:100000. Geology of the Zagreb sheet) Institut za geološka istraživanja, Zagreb (1972) Savezni geološki zavod, Beograd, 81 p. (in Croatian)

Šparica, M., Pavelić, D., Miknić, M. and Brkić, M. (1988): Miocenski biolititi u području Dilj gore (Slavonija, istočna Hrvatska). Geološki glasnik, Posebna izdanja, 6, 243-251, Titograd. (in Croatian)

Taylor, P.D., Hara, U. and Jasionowski, M. (2006): Unusual early development in a cyclostome bryozoan from the Ukrainian Miocene. Linzer biol. Beitr., 38/1, 55-64.

Tišljar, J. (1993): Sedimentary bodies and depositional models for the Miocene oil-producing areas of Ladislavci, Beničanci and Obod. Nafta, 44 (10), 531-542.

Vescogni, A., Bosellini, F.R., Reuter, M. and Brachert, T.C. (2008): Vermetid reefs and their use as palaeobathymetric markers: New insights from the Late Miocene of the Mediterranean (Southern Italy, Crete). Palaeogeography, Palaeoclimatology, Palaeoecology, 267, 89-101. DOI 10.1016/j.palaeo.2008.06.008

Vrsaljko, D., Pavelić, D. and Bajraktarević, Z. (2005): Stratigraphy and palaeogeography of Miocene Deposits from the Marginal Area of Žumberak Mt. and Samoborsko Gorje Mts. (Northwestern Croatia). Geologia Croatica, 58/2, 133150.

Vrsaljko, D., Pavelić, D., Miknić, M., Brkić, M., Kovačić, M., Hećimović, I., Hajek-Tadesse,V., Avanić, R. and Kurtanjek, N. (2006): Middle Miocene (Upper Badenian/Sarmatian) palaeoecology and evolution of the environments in the area of Medvednica Mt. (North Croatia). Geologia Croatica, 59/1, 51-63.

Vrsaljko, D., Hećimović, I. and Avanić, R. (2007): Miocene deposits of Northern Croatia. In: Grgasović, T. and Vlahović, I. (eds.): 9th International Symposium on Fossil Algae, Field Trip Guidebook and Abstracts. Croatian Geological Survey, Zagreb, 143-153.

Wiedl, T., Harzhauser, M., Kroh, A., Ćorić, S. and Piller, W.E. (2013): Ecospace variability along a carbonate platform at the northern boundary of the Miocene reef belt (Upper Langhian, Austria). Palaeogeography, Palaeoclimatology, Palaeoecology, 370, 232-246. DOI 10.1016/j.palaeo.2012.12.015

Zágoršek, K., Holcová, K., Nehyba, S., Kroh, A. and Hladilová, Š. (2008a): The invertebrate fauna of the Middle Miocene (Lower Badenian) sediments of Kralice nad Oslavou (Central Paratethys, Moravian part of the Carpathian Foredeep). Bulletin of Geosciences, 84 (3), 465-496. DOI 10.3140/bull.geosci.1078

Zágoršek, K., Holcová, K. and Třasoň, T. (2008b): Bryozoan event from Middle Miocene (Early Badenian) lower neritic sediments from the locality Kralice nad Oslavou (Central Paratethys, Moravian part of the Carpathian Foredeep). International Journal of Earth Sciences, 97, 835-850.

Zágoršek, K., Filipescu, S. and Holcová, K. (2010): New Middle Miocene bryozoan from Gârbova de Sus (Romania) and their relationship to the sedimentary environment. Geologica Carpathica, 61, 495-512. doi: 10.2478/v10096-010-00312

http://www.stratigraphy.org/ICSchart/ChronostratChart2015-01.pdf, September 2015

The Mining-Geology-Petroleum Engineering Bulletin, 2015, pp. 19-29 @ The Author(s), DOI: 10.17794/rgn.2016.1.2 


\section{Sažetak}

Grebeni i druge biogene tvorevine u miocenskim naslagama Sjevernohrvatskoga bazena - čudesna raznolikost koju tek treba istražiti

Tijekom početne faze srednjomiocenske transgresije marinski organizmi naselili su novonastalo more Paratethys. Zahvaljujući pogodnim klimatskim i okolišnim uvjetima život je bio posebno raznolik na grebenima i grebenolikim strukturama. Miocenske biogene tvorevine na raznim lokalitetima u području sjeverne Hrvatske pokazuju raznolikost fosilnih zajednica i litoloških osobina. Glavni grebenotvorci bili su mahovnjaci, koralinacejske alge, kamenice, vermetidi, spužve i serpulidi. Glavni ekološki faktori koji su kontrolirali grebensku biotu bili su donos čestica i hraniva s kopna i iz dubina vode. Tipovi litofacijesa pokazuju veliku sličnost s gornjolangijskim (srednji baden) gorjem Leitha u Austriji, a mogu se usporediti i s miocenskim i recentnim grebenskim strukturama u Mediteranu. Razne vrste miocenskih grebenolikih tvorevina pokazuju različitu šupljikavost i druge petrofizičke osobine.

Koraligenske biokonstrukcije danas nastaju kao konkrecije u slabo osvijetljenim uvjetima, pogodnim scijafilnim algama, u vodi relativno hladne, ali stalne temperature, jednoličnoga saliniteta i niske energije. Nastaju na stjenovitoj podlozi i na pokretnoj podlozi u donjoj litoralnoj zoni i katkad na obalnome detritusu. Rast im započinje nastankom rodolita unutar pijeska i šljunka (platformske koraligenske zajednice). Aktualistički princip pomaže nam razumjeti ranu pojavu koraligenskih tvorevina na početku srednjomiocenske transgresije.

Početna rodolitna faza rezultira slabo vezanim bioklastičnim naslagama. Dijagenetski procesi dodatno povećavaju njihovu šupljikavost, uslijed otapanja aragonitnih bioklasta. To je otapanje agresivno u vrlo plitkim staništima i povećava se $\mathrm{s}$ dubinom. Promjenjiva šupljikavost koraligenskih tvorevina istraživana je tijekom terenskoga rada na području Medvednice. Uzorci stijena s velikim rodolitima već na prvi pogled pokazuju najveću šupljikavost, dok su briozojsko-koralinacejski frejmstoni najkompaktniji. Time se otvara prostor za daljnja istraživanja ovih zanimljivih naslaga.

\section{Ključne riječi}

biogene tvorevine, baden, Središnji Paratethys, Hrvatska

The Mining-Geology-Petroleum Engineering Bulletin, 2015, pp. 19-29 @ The Author(s), DOI: 10.17794/rgn.2016.1.2 
The Mining-Geology-Petroleum Engineering Bulletin, 2015, pp. 19-29 ( ) The Author(s), DOI: 10.17794/rgn.2016.1.2 